\title{
Struktur Semantis Verba Kiru 'Potong' Kajian Metabahasa Semantik Alami
}

\author{
Sifta Sari Dewi*, Mulyadi, Mhd. Pujiono \\ Fakultas Ilmu Budaya Universitas Sumatera Utara Medan \\ *siftasaridewi@yahoo.com
}

\begin{abstract}
Abstrak
Penelitian ini bertujuan untuk menganalisis kategorisasi dan makna verba kiru 'potong' dengan teori Metabahasa Semantik Alami. Penelitian ini menggunakan pendekatan kualitatif. Pengumpulan data dilakukan dengan metode cakap. Analisis data menggunakan metode padan dan metode agih. Penyajian hasil data dilakukan dengan metode formal dan informal. Terdapat 21 verba kiru 'potong'. Hasil penelitian menunjukkan bahwa verba kiru 'potong' terdiri atas dua kategori dilihat dari tabel makna asali bahasa Indonesia dan bahasa Jepang, yaitu 1) 'X melakukan sesuatu pada seseorang dibagi atas dua subkategori yaitu, yaitu 1.1) 'X melakukan sesuatu pada seseorang dengan sesuatu dan 1.2) 'X melakukan sesuatu pada seseorang dalam waktu tertentu dan 2) 'X melakukan sesuatu pada sesuatu' dibagi atas dua subkategori, yaitu 2.1) 'X melakukan sesuatu pada sesuatu dengan sesuatu' dan 2.2) ' $X$ melakukan sesuatu pada sesuatu dalam waktu tertentu'. Selanjutnya, makna verba kiru 'potong' dibentuk oleh makna asali melakukan (suru) dan terjadi (okoru/okiru) yang berkombinasi membentuk sintaksis makna universal ' $X$ melakukan sesuatu pada $Y$, sesuatu terjadi pada $Y^{\prime}$.
\end{abstract}

Kata kunci: verba kiru 'potong'; struktur semantis; metabahasa semantik alami

\begin{abstract}
(Title: Semantic Structures Of Kiru 'Cut' Verbs) This study aims to analyze the categorization and meaning of the kiru "cut" verbs by Natural Semantic Metalangue theory.This research uses a qualitative approach. The categorization and meaning are analyzed by the Natural Semantic Metalangue Theory. Data collection is done by competent methods. Data analysis uses the identity and distributional methods. The presentation of data results is done by formal and informal methods. There are 21 kiru 'cut' verbs. The results showed that the kiru 'cut' verbs consisted of two categories seen from the Indonesian and Japanese semantic prime table, namely 1) ' $X$ does something to someone' divided into two subcategories, namely 1.1) 'X does something to someone with something' and 1.2)' $X$ does something on someone in a certain time' and 2) ' $X$ doing something on something' is divided into two subcategories, namely 2.1)'X does something on something with something' and 2.2) ' $X$ does something on something in a certain time'. Furthermore, the meaning of the kiru 'cut' verbs are formed by the original meaning of doing (suru) and happening (okoru/okiru) which combine to form the syntax of universal meaning ' $X$ do something on $Y$, something happens to $Y^{\prime}$.
\end{abstract}

Keywords: kiru 'cut' verbs; semantic structures; natural semantic metalangue 
Izumi, Volume 8 No 2, 2019

e-ISSN: 2502-3535 p-ISSN: 2338-249X

Tersedia online di http://ejournal.undip.ac.id/index.php/izumi

\section{PENDAHULUAN}

Salah satu aktivitas budaya pada masyarakat Jepang berkaitan dengan penggunaan pisau. Pisau merupakan alat sentral dalam memotong ikan di masyarakat Jepang.Masyarakat Jepang dikenal gemar mengonsumsi ikan. Budaya makan ikan ini sudah dilakukan sebelum agama Buddha masuk ke Jepang. Budaya ini dimulai sejak zaman Jomon (jomon jidai) (14.000-400 SM). Pada periode ini mata pencaharian sehari-hari warga adalah berburu dan menangkap ikan (Hardiyanto, 2013: 4).

Secara semantis, memotong merupakan bagian dari verba tindakan. Dalam memotong ikan, masyarakat Jepang memiliki tata cara tertentu. Ikan yang akan dipotong dibersihkan terlebih dahulu sisiknya dengan menggunakan うろこ取 り (urokotori) yaitu pisau khusus untuk memisahkan sisik dari lapisan kulit ikan (lihat gambar 1) dan peralatan yang digunakan untuk memotong ikan menggunakan 刃 物 (hamono) (alat pemotong) khusus yang digunakan untuk tiap jenis ikan. Seperti yang dapat dilihat di gambar 2, hamono khusus yang digunakan ini dinamakan 刺身包丁 (sashimi boucho) yaitu kumpulan pisau yang digunakan untuk memotong ikan mentah, yang terdiri dari 蛸引き包丁 (takohiki houchou), 柳 刃包丁(yanagiba houcho), dan ふぐ゙引き (fuguhiki) (Hardiyanto, 2013: 6-7).

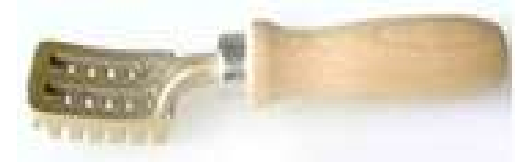

Gambar 1

うろこ取り(urokotori)

Sumber: https://zhuanlan.zhihu.com/p/24823641

Verba kiru 'potong' tergolong unik. Ada kata-kata dalam bahasa Jepang yang memiliki makna sama tetapi memiliki ciri yang berbeda. Misalnya, verba yaburu (破 る)'merobek' dan saku (裂く)'merobek' yang dipahami sebagai dua kata yang memiliki makna yang sama. Namun, yaburu (破る)'merobek' mempunyai ciri khusus, yaitu berobjek kemeja, sedangkan verba saku (裂<)'merobek' mempunyai ciri khusus, yaitu berobjek kertas. Hal ini tampak pada contoh berikut ini:

(1) a. 私は紙を破る/裂く。

Watashi wa kami o yaburu/saku. (Kamus Jepang-Indonesia)

Saya Part kertas Part merobek 'Saya merobek kertas.'

b. 私はシャツを裂く/??破る。

Watashi wa shatsu o saku/yaburu. (Kamus Jepang-Indonesia)

Saya Part kemeja Part merobek

'Saya merobek kemeja.'

Verba kiru 'potong' dapat dikelompokkan ke dalam kategori atau subkategori, yaitu berdasarkan objek dan alat yang digunakan.

Teori yang digunakan dalam penelitian ini adalah teori Metabahasa Semantik Alami (MSA) yang dipelopori oleh Wierzbicka (1996). Konsep yang terdapat dalam teori MSA antara lain makna asali (semantic primitive/semantic prime), polisemi takkomposisi (non-compositional polysemy), dan sintaksis makna universal (universal syntax).

Makna asali adalah seperangkat makna yang tidak berubah yang telah diwarisi oleh manusia sejak lahir. Dengan kata lain, makna asali merupakan makna pertama dari sebuah kata yang tidak mudah berubah walaupun ada perubahan kebudayaan (perubahan zaman). Berdasarkan hasil penelitian Wierzbicka (1996) ditemukan makna asali sejumlah bahasa di dunia, seperti bahasa Cina, Jepang, Aceh, Inggris, dan bahasa Aborigin di Australia. Pada tahun 1972, dia menemukan 14 buah makna asali, kemudian pada tahun 1980 menjadi 15 buah makna asali. Terakhir, Wierzbicka (1996) dan Goddard (2006) mengusulkan 63 buah makna asali seperti yang dapat dilihat pada tabel 1 . 
Izumi, Volume 8 No 2, 2019

e-ISSN: 2502-3535 p-ISSN: 2338-249X

Tersedia online di http://ejournal.undip.ac.id/index.php/izumi

Tabel 1

Perangkat Makna Asali Bahasa Inggris, Jepang, dan Indonesia

\begin{tabular}{|c|c|}
\hline Komponen & Elemen Makna Asali \\
\hline Substantif & $\begin{array}{c}\text { I Watashi Aku, You Anata Kamu, Someone Dareka Seseorang, } \\
\text { Peoplehito/Hitobito Orang, Something Nanika/Mono/Koto } \\
\text { Sesuatu/Hal, Body Karada Tubuh }\end{array}$ \\
\hline Substantif Relasional & Kind Shurui Jenis, Part Bubun Bagian \\
\hline Pewatas & This Kore Ini, The Same Onaji Sama, Other/Else Hoka Lain \\
\hline Penjumlah & $\begin{array}{l}\text { One Hito-/Ichi Satu, Two Futa-/Ni Dua, Much/Many Takusan Banyak, } \\
\text { Some Ikutsuka Beberapa, All Minna Semua }\end{array}$ \\
\hline Evaluator & Good Ii Baik, Bad Warui Buruk \\
\hline Deskriptor & Big Ookii Besar, Small Chiisai Kecil \\
\hline Predikat Mental & $\begin{array}{c}\text { Think Omou Pikir, Know Shiru Tahu, Want Hoshii/-Tai/Nozomu Ingin, Feel } \\
\text { Kanjiru Rasa, See Miru Lihat, Hear Kiku Dengar }\end{array}$ \\
\hline Ujaran & Say Iu Ujar, Words Kotoba Kata, True Hontoo Benar \\
\hline $\begin{array}{l}\text { Tindakan,Peristiwa, } \\
\text { Gerakan, Perkenaan }\end{array}$ & $\begin{array}{c}\text { Do Suru Laku, Happen Okoru/Okiru Terjadi, Move Ugoku Gerak, } \\
\text { Touch Fureru Sentuh }\end{array}$ \\
\hline $\begin{array}{l}\text { Tempat, Keberadaan, } \\
\text { Milik, dan } \\
\text { Spesifikasi }\end{array}$ & $\begin{array}{c}\text { Be (Somewhere) (Dokoka) Iru/Aru Ada (Dimana), There Is/Exist Iru/Aruada, } \\
\text { Have Motsu Punya, Be (Someone/Something) Dearu Adalah } \\
\text { (Seseorang/Sesuatu) }\end{array}$ \\
\hline Hidup Dan Mati & Live Ikiru Hidup, Dead Shinu Mati \\
\hline Waktu & $\begin{array}{l}\text { When/Time Itsu/Toki Bila/Waktu, Now Ima Sekarang, Before Mae Sebelum, } \\
\text { After Ato Setelah, A Long Time Nagai Aida Lama, A Short Time Mijikai Aida } \\
\text { Singkat, For Some Time Shibaraku No Aida Sebentar, Moment Suguni Saat }\end{array}$ \\
\hline Ruang & $\begin{array}{c}\text { Where/Place Doko-Tokoro (Di)Mana/Tempat, Here Koko (Di) Sini, Above Ue } \\
\text { (Di) Atas, Below Shita (Di) Bawah, Far Tooi Jauh, Near Chikai Dekat, Side Men } \\
\text { Sisi, Inside Naka (Di) Dalam }\end{array}$ \\
\hline Konsep Logis & $\begin{array}{c}\text { Not -Nai Tidak, Maybe Tabun Mungkin, Can Dekiru Dapat, Because -Kara } \\
\text { Karena, If Moshi (Ba) Jika }\end{array}$ \\
\hline Augmentor Intensifier & Very Sugoku Sangat, More Motto Lebih \\
\hline Kesamaan & Like/As Yoo/Doo/Yooni Seperti \\
\hline
\end{tabular}

Sumber: Mulyadi (2012: 38) dan Goddard,C dan Anna Wierzbicka(2009: 92).

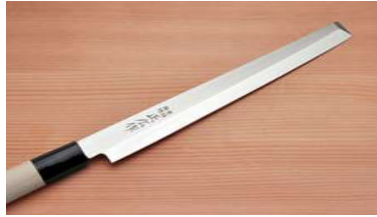

蛸引き包丁
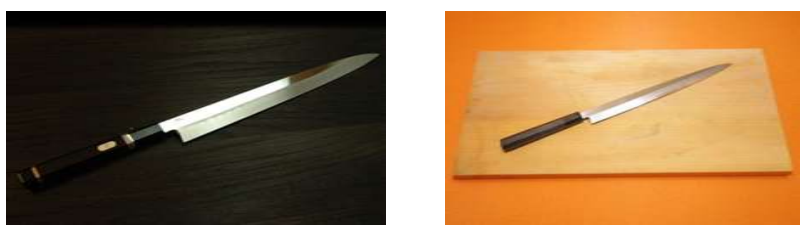

ふぐ引き

Gambar 2

刺身包丁 (sashimi boucho)

(pisau untuk memotong ikan mentah dan bahan makanan laut)

Sumber: https://zhuanlan.zhihu.com/p/24823641 
Izumi, Volume 8 No 2, 2019

e-ISSN: 2502-3535 p-ISSN: 2338-249X

Tersedia online di http://ejournal.undip.ac.id/index.php/izumi

Berkaitan dengan struktur semantis verba kiru 'potong' diisyaratkan kemungkinan elemen yang dapat berfungsi sebagai predikat, yakni elemen yang dapat disamakan dengan verba: tindakan, peristiwa, gerakan (dosuru laku, happen okoru/okiru terjadi).

Struktur semantis pada verba kiru 'potong' mengandung enam bagian, yaitu: yaitu Kerangka Leksiko Sintaktis (LexicoSyntactic Frame), Skenario Motivasi Prototipe (Prototypical Motivational Scenario), Alat (Instrument), Bagaimana seseorang menggunakan alat (How the person uses the instrument), Apa yang terjadi pada objek (What is happening to the object), dan Hasil akhir (Potential Outcome) (Goddard dan Wierzbicka, 2009: 63). Berikut adalah penjelasan verba cutting menurut Goddard dan Wierzbicka (2009: 64).

Someone $(X)$ was cutting thing $Y$ (e.g. some paper, a cake) with thing $Z$.

1) Kerangka Leksiko Sintaktis (LexicoSyntactic Frame)

someone $X$ was doing something to thing $Y$ with thing $Z$ for some time

because of this, something was happening at the same time to thing $Y$ as this someone wanted

\section{2) Skenario Motivasi Prototipe (Prototypical Motivational Scenario)}

people do something like this when they do something to something

because a short time before, they thought about this something like this:

"I want this something not to be one thing anymore

I want this something to be two things

I want these two things to have straight [M] edges [M]"
3) Alat (Instrument)

when someone does something like this, they do it with something

this something is not a part of this someone's body

this something has a sharp [M] edge [M]

4) Bagaimana seseorang menggunakan alat (how the person uses the instrument)

when someone does something like this with something, one of this someone's hands [M] touches this thing in some places all the time because of this, when this hand [M] moves as this someone wants, this thing moves at the same time as this someone wants

5) Apa yang terjadi pada objek (What is happening to the object)

when someone does something like this with something to something else, the sharp [M] edge [M] of this thing touches this other thing in some places for some time because of this, when this someone's hand $[M]$ moves as this someone wants, something happens to this other thing in these places

6) Hasil akhir (Potential Outcome)

if it happens like this for some time, after this, this other thing can be two things

Selanjutnya, konsep yang digunakan dalam penelitian ini yaitu verba kiru 'potong', komponen semantis, kategorisasi, makna, dan struktur semantis. Hubungan antara konsep dapat dilihat pada gambar 3 .

Penelitian yang berhubungan dengan verba kiru 'potong' sudah pernah dilakukan oleh beberapa ahli. Misalnya, penelitian Goddard dan Wierzbicka (2009) yang berjudul Contrastive semantics of physical activity verbs: 'Cutting' and 'chopping' in English, Polish, and Japanese. Goddard dan Wierzbicka meneliti tentang perbedaan 
cutting 'potong' dan chopping 'cincang' dalam bahasa Inggris, Polandia, dan Jepang.

Penelitian Lumban Gaol (2014) yang berjudul Verba 'Potong' dalam Bahasa Batak Toba. Lumban Gaol meneliti kategorisasi dan makna verba potong dalam bahasa Batak Toba.

Penelitian Putra (2014) yang berjudul Verba "Memotong" dalam Bahasa Bali Kajian Metabahasa Semantik Alami. Putra meneliti kategorisasi, makna, dan peran semantis verba memotong dalam bahasaBali.

Penelitian Loe (2015) yang berjudul Verba Memotong Bahasa Rote Dialek Dengka: Kajian Meta Semantik Alami (MSA). Loe meneliti kategorisasi dan makna verba memotong dalam bahasa Rote.

Diluar dari penelitian verba kiru 'potong', terdapat juga penelitian tentang verba lainnya yang dilakukan oleh beberapa ahli yaitu: Rehana (2016) yang berjudul Struktur dan Peran Semantis Verba 'ambil' dalam Bahasa Aceh. Rehana meneliti meneliti kategorisasi, makna, dan peran semantis verba ambil dalam bahasa Aceh.

Suktiningsih (2017) yang berjudul Struktur Semantis Verba 'Membawa' Bahasa Sunda: Kajian Metabahasa Semantik Alami. Suktiningsih meneliti kategorisasi dan makna verba membawa dalam bahasa Sunda.

Wiriani (2017) yang berjudul Typology Lexical Verb 'To Use' in Japan: Natural Semantics Metalanguage Study. Wiriani meneliti verba memakai dalam bahasa Jepang

Dari penjelasan di atas terlihat bahwa kajian semantik verba kiru 'potong' belum pernah dilakukan. Dalam penelitian ini, hanya diperlihatkan semantik verba kiru 'potong' mencakup kategorisasi dan makna.

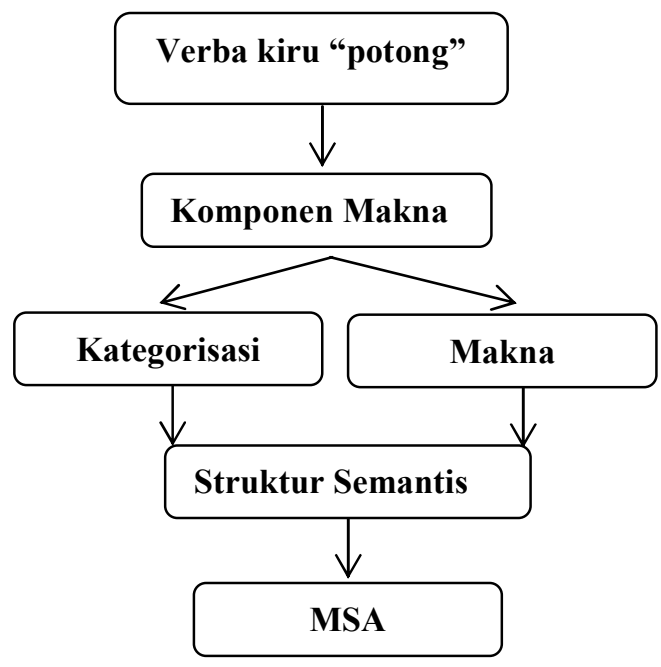

Gambar 3 Hubungan Antar Konsep

\section{METODE PENELITIAN}

Data yang dikumpulkan dalam penelitian ini berupa ragam kalimat yang mengandung verba kiru 'potong'. Sumber data dalam penelitian ini adalah data lisan. Data lisan bersumber dari informan yang merupakan penutur asli bahasa Jepang.

Metode yang digunakan untuk mengumpulkan data adalah metode cakap (Sudaryanto, 2015: 208). Data lisan dikumpulkan dengan menggunakan metode cakap dengan teknik dasar teknik pancing. Dengan teknik pancing, peneliti akan memancing narasumber untuk memunculkan data yang diinginkan (Sudaryanto, 2015: 208). Dalam penelitian ini, peneliti menetapkan dua orang informan berjenis kelamin pria. Informan ini adalah penutur asli bahasa Jepang.

Data verba kiru 'potong' yang telah dikumpulkan kemudian dikelompokkan berdasarkan objek yang dipotong seperti seseorang (objek yang bernyawa, yaitu manusia, hewan, dan tumbuhanatau sesuatu (objek yang tidak bernyawa), kemudian sesuatu (alat yang digunakan), dan waktu dalam melakukan tindakan. Data dianalisis 
dengan menggunakan metode agih yang didukung dengan metode padan terutama dalam menentukan makna verba (Sudaryanto, 2015: 15-18). Cara kerja kedua metode tersebut dapat diringkas seperti di bawah ini.

Metode padan, alat penentunya justru bagian dari bahasa yang bersangkutan itu sendiri (Sudaryanto, 2015:18). Metode padan berguna untuk mengidentifikasi butirbutir leksikal yang secara intuitif tergolong verba kiru 'potong' untuk menetapkan kategorisasi verba kiru 'potong'. Butir-butir leksikal yang termasuk verba kiru 'potong' dikumpulkan dan verba kiru 'potong' tersebut dikelompokkan berdasarkan ciri semantisnya. Alat penentu dalam metode agih berupa bagian atau unsur dari bahasa objek sasaran penelitian itu sendiri (Sudaryanto, 2015:19). Metode agih berperan penting dalam menganalisis struktur semantis verba kiru 'potong'.

Hasil penelitian data disajikan dengan dua metode informal dan formal. Metode penyajian informal adalah perumusan dengan kata-kata biasa, walaupun dengan terminologi yang teknis sifatnya; sedangkan penyajian formal adalah perumusan dengan apa yang umum dikenal sebagai tanda dan lambang-lambang (Sudaryanto, 2015: 240).

\section{HASIL DAN PEMBAHASAN}

\section{Kategorisasi Verba KIRU 'POTONG'}

Verba kiru 'potong' dikelompokkan berdasarkan ciri semantisnya. Berdasarkan ciri semantisnya verba potong dibagi menjadi dua kategori, yaitu ' $\mathrm{X}$ melakukan sesuatu pada seseorang' dan ' $\mathrm{X}$ melakukan sesuatu pada sesuatu'.

\section{Kategori ' $X$ melakukan sesuatu pada seseorang'}

Kategori ' $\mathrm{X}$ melakukan sesuatu pada seseorang' mengacu kepada objek yang bernyawa serta alat dan waktu yang dilakukan saat peristiwa memotong. Objek bernyawa yang dimaksud adalah manusia, hewan, dan tumbuhan (Kridalaksana, 2007: 68). Untuk lebih jelasnya, kategorisasi verba kiru 'potong' dapat dilihat pada subkategori berikut ini.

\subsection{Subkategori ' $X$ melakukan sesuatu pada seseorang dengan sesuatu'}

Komponen ' $\mathrm{X}$ melakukan sesuatu pada seseorang 'dengan sesuatu' terdapat pada verba kiru' (切る) 'menebas/memenggal', $\mathrm{kiru}^{2}$ (切る) 'menyayat', tosatsu suru (屠殺 する) 'menyembelih', sanpatsu suru (散髮 する ) 'memangkas', karu' ( 刈る) 'memangkas', dan soru (剃る) 'mencukur'. Jenis alat yang digunakan antara lain pedang, kaca, pisau, alat cukur, gunting, dan pisau cukur. Keenam verba tersebut menerangkan tindakan memotong pada bagian tubuh manusia atau hewan dengan menggunakan alat seperti pada contoh 1-6.

Pada contoh (1) verba kiru (切る) 'menebas/memenggal' mensyaratkan objek yang berupa leher pria dan menggunakan alat berupa pedang. Pada contoh (2) verba kiru $^{2}$ (切る) 'menyayat' mensyaratkan objek yang berupa tangan. Pada contoh (3) verba tosatsu suru (屠 殺 す る) 'menyembelih'mensyaratkan objek yang berupa lembu dan menggunakan pisau dalam melakukan tindakan.

Pada contoh (4) verba sanpatsu suru (散 髪する) 'memangkas' mensyaratkan objek yang kecil berupa rambut dan menggunakan alat berupa alat cukur dan gunting. Pada contoh (5) verba karu (刈る) 'memangkas' mensyaratkan objek yang kecil berupa bulu domba dan menggunakan alat berupa alat cukur. Sedangkan pada contoh (6) verba 
soru (剃る) 'mencukur' mensyaratkan objek yang kecil berupa kumis dan menggunakan alat berupa pisau cukur listrik dalam melakukan tindakan.

Contoh (1)-(6):

(1) 彼は刀で男の首を切った。

Kare wa katana de otoko no kubi o kitta. (Data Lisan-I, /01/07/18)

Dia (lk) Part pedang Part pria Part leher Part sudah menebas/memenggal

'Dia sudah menebas/memenggal leher pria itu dengan pedang.'

(2) 彼はガラスで手を切った。

Kare wa garasu de te o kitta. (Data Lisan-I, /01/07/18)

Dia (lk) Part kaca Part tangan Part sudah menyayat

'Dia sudah menyayat tangannya dengan kaca.'

(3) 彼はナイフで牛を屠殺した。

Kare wa naifu de ushi o tosatsu shita. (Data Lisan-I, /01/07/18)

Dia (lk) Part pisau Part lembu Part sudah menyembelih

'Dia sudah menyembelih lembu itu dengan pisau.'

(4) 彼はバリカンとハサミで髪を散髮する。

Kare wa barikan to hasami dekamio sanpatsu suru. (Data Lisan-I, /01/07/18)

Dia (lk) Part alat cukur Konj gunting Part rambut Part memangkas

'Dia memangkas rambutnya dengan alat cukur dan gunting.'

(5) 彼らはバリカンで羊の毛を刚る。

Karera wa barikan de hitsuji no ke o karu. (Data Lisan-I, /01/07/18)

Mereka Part alatcukur Part domba Part bulu Part memangkas

'Mereka memangkas bulu domba dengan alat cukur.'

(6) 彼は電気カミソリで顔を剃る。

Kare wa denki kamisori de hige o soru. (Data Lisan-I, /01/07/18)

Dia (lk) Part pisau cukur listrik Part kumis Part mencukur

'Dia mencukur kumisnya dengan pisau cukur'.

\subsection{Subkategori ' $\mathrm{X}$ melakukan sesuatu pada seseorang dalam waktu tertentu'}

Komponen 'X melakukan sesuatu pada seseorang dalam waktu tertentu' terdapat pada verba oru (折る) 'mematahkan', tsumu (抓む) 'memetik', kiru' (切る) 'mengiris', kizamu (刻む) 'mencincang', $\operatorname{karu}^{2}$ (刚る) 'membabat', karu'(刚る) 'menuai', bassai suru (伐採する) 'menebang', dan waru (割 る) 'membelah'. Kedelapan verba tersebut menerangkan tindakan memotong yang mengacu pada tumbuhan dalam waktu tertentu seperti pada contoh (7)-(14).

Pada contoh (7) verba oru (折 る) 'mematahkan' mensyaratkan objek yang kecil berupa ranting pohon dan kata sifat cepat. Sedangkan pada contoh (8) verba tsumu (抓む) 'memetik' mensyaratkan objek yang kecil berupa bunga dan kata sifat cepat dalam melakukan tindakan. 
Izumi, Volume 8 No 2, 2019

e-ISSN: 2502-3535 p-ISSN: 2338-249X

Tersedia online di http://ejournal.undip.ac.id/index.php/izumi

Pada contoh (9) verba $\mathrm{kiru}_{3}$ (切る) 'mengiris' mensyaratkan objek yang kecil berupa daun bawang dan kata sifat cepat. Sedangkan pada contoh (10) verba kizamu(刻む) 'mencincang' mensyaratkan objek yang kecil berupa bawang putih dan kata sifat cepat dalam melakukan tindakan.

Pada contoh (11) verba $\mathrm{karu}_{2}$ (刈 る) 'membabat' mensyaratkan objek yang kecilberupa rumput dan kata sifat cepat. Sedangkan pada contoh (12) verba Karu $_{3}$ (XI]
る) 'menuai'mensyaratkan objek yang kecil berupa padi dan kata sifat cepat dalam melakukan tindakan.

Pada contoh (13) bassai suru (伐採す る) 'menebang' mensyaratkan objek yang besar berupa pohon besar dan kata sifat perlahan. Sedangkan pada contoh (14) verba waru (割る) 'membelah' mensyaratkan objek yang besar berupa pohon dan kata sifat cepat dalam melakukan tindakan.

Contoh (7)-(14):

(7) 彼は早く枝を折る。

Kare wa hayaku eda o oru. (Data Lisan-I, /01/07/18)

Dia (1k) Part cepat ranting Part mematahkan

'Dia mematahkan ranting pohon dengan cepat.'

(8) 私は早く花を抓む。

Watashi wa hayaku hana o tsumu. (Data Lisan-I, /01/07/18)

Saya Part cepat bunga Part memetik

'Saya mematahkan bunga dengan cepat.'

(9) お母さんは早くねぎを切る。

Okaasan wa hayaku negio kiru. (Data Lisan-II, /26/08/18)

Ibu Part cepat daun bawang Part mengiris

'Ibu mengiris daun bawang dengan cepat.'

(10) お母さんは早くにんにくを刻む。

Okaasan wa hayaku ninniku o kizamu. (Data Lisan-II, /26/08/18)

Ibu Part cepat bawang putih Part mencincang

'Ibu mencincang bawang putih dengan cepat.'

(11) 彼は庭で早く芝を刚る。

Kare wa niwa de hayaku shiba o karu. (Data Lisan-II, /26/08/18)

Dia (lk) Part taman Part cepat rumput Part membabat

'Dia membabat rumput di taman dengan cepat.'

(12) 農家は水田で早く稲を刈る。

Nouka wa suidende hayaku ine o karu. (Data Lisan-II, /26/08/18)

Petani Part sawah Part cepat padi Part menuai

'Petani menuai padi di sawah dengan cepat.'

(13) 彼は遅く大木を伐採する。

Kare wa osoku taibokuo bassai suru. (Data Lisan-II, /26/08/18)

Dia (lk) Part perlahan pohon besar Part menebang

'Dia menebang pohon besar secara perlahan.'

(14) 彼は早く木を割る。 
Kare wa hayaku ki o waru. (Data Lisan-II, /26/08/18)

Dia (lk) Part cepat pohon Part membelah

'Dia membelah pohon dengan cepat.

2. Kategori ' $X$ melakukan sesuatu pada sesuatu'

Kategori ' $\mathrm{X}$ melakukan sesuatu pada sesuatu' mengacu kepada objek yang tidak bernyawa serta alat dan waktu yang dilakukan saat peristiwa memotong. Objek yang tidak bernyawa yang dimaksud adalah benda/sesuatu yang tidak bernyawa (Kridalaksana, 2007: 68). Untuk lebih jelasnya, kategorisasi verba kiru 'potong' dapat dilihat pada subkategori berikut ini.

\subsection{Subkategori ' $X$ melakukan sesuatu pada sesuatu dengan sesuatu'}

Komponen ' $\mathrm{X}$ melakukan sesuatu pada sesuatu dengan sesuatu' terdapat pada verba yaburu (破る) 'merobek', saku (裂く) 'merobek', kiru 4 (切る) 'memotong', tatsu (裁つ) 'memotong', dan saidan suru (裁断 する) 'memotong'. Jenis alat yang digunakan antara lain: tangan dan gunting. Kelima verba tersebut menerangkan tindakan memotong yang mengacu pada sesuatu yang tidak bernyawa dengan menggunakan alat seperti pada contoh (15)(19).

Pada contoh (15) verba yaburu (破る) 'merobek' mensyaratkan objek yang berupa kertas dan menggunakan alat berupa tangan. Sedangkan pada contoh (16) verba saku (裂 <) 'merobek' mensyaratkan objek yang berupa jeans dan menggunakan alat berupa gunting dalam melakukan tindakan.

Pada contoh (17) verba kiru $_{4}$ (切る) 'memotong' mensyaratkan objek yang kecil berupa gula sachet dan menggunakan alat berupa tangan. Pada contoh (18) verba tatsu (裁つ) 'memotong' mensyaratkan objek yang kecil berupa kain dan menggunakan alat berupa gunting. Sedangkan pada contoh (19) verba saidan suru (裁断する) 'memotong' mensyaratkan objek yang kecil berupa kertas dan menggunakan alat berupa gunting dalam melakukan tindakan.

Contoh (15)-(19):

（15）破る

彼は手で紙を 裂く

yaburu

Kare wa te de kami o saku. (Data Lisan-I, /01/07/18)

Dia (lk) Part tangan Part kertas Part merobek

'Dia merobek kertas dengan tangan.'

(16)

裂く

彼女はハサミでジーンズを＼cjkstart破る

saku

Kanojo wa hasami de jiinzu o yaburu. (Data Lisan-I, /22/07/18)

Dia (pr) Part gunting Part jeans Part merobek 
'Dia merobek jeans dengan gunting.'

(17) 彼はハサミで砂糖の袋を切る。

Kare wa hasami de fukuro no satou o kiru. (Data Lisan-I, /01/07/18)

Dia (lk) Part gunting Part sachet Part gula Part memotong

'Dia memotong gula sachet dengan gunting.'

(18) 私はハサミで布を裁つ。

Watashi wa hasami de nuno o tatsu. (Data Lisan-I, /01/07/18)

Saya Part gunting Part kain Part memotong

'Saya memotong kain dengan gunting.'

(19) 私は八サミで紙を裁断する。

Watashi wa hasami de kami o saidan suru. (Data Lisan-I,/01/07/18)

Saya Part gunting Part kertas Part memotong

'Saya memotong kertas dengan gunting.'

\subsection{Subkategori ' $\mathrm{X}$ melakukan sesuatu pada sesuatu dalam waktu tertentu'}

Komponen ' $\mathrm{X}$ melakukan sesuatu pada sesuatu dalam waktu tertentu' terdapat pada verba kirus (切る) 'menggergaji' dan

(20) 彼は遅く板を切る。

Kare wa osoku ita o kiru. (Data Lisan-II, /26/08/18)

Dia (lk) Part perlahan papan Part menggergaji

'Dia menggergaji papan secara perlahan.'

(21) 彼は早く鉄板を切断する。

Kare wa hayaku teppan o setsudan suru. (Data Lisan-II, /26/08/18)

Dia (lk) Part cepat pelat besi Part memotong

'Dia memotong pelat besidengan cepat.'

Pada contoh (20) verba kiru5 (切る) 'menggergaji' mensyaratkan objek yang besar berupa papan dan kata sifat perlahan. Pada contoh (21) verba setsudan suru (切断 する) ‘memotong' mensyaratkan objek yang setsudan suru (切断する) 'memotong'. Kedua verba tersebut menerangkan tindakan memotong yang mengacu pada sesuatu yang tidak bernyawa dalam waktu tertentu seperti pada contoh berikut ini.

Tabel 2

Kategorisasi Verba KIRU 'POTONG'

\begin{tabular}{|c|c|c|}
\hline Kategori & Subkategori & Bahasa Jepang \\
\hline $\begin{array}{l}\text { 'X melakukan sesuatu pada } \\
\text { seseorang' }\end{array}$ & $\begin{array}{l}\text { 'X melakukan sesuatu pada } \\
\text { seseorang dengan sesuatu' }\end{array}$ & 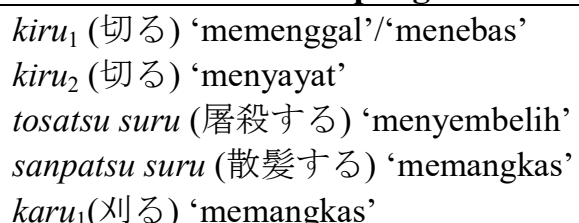 \\
\hline
\end{tabular}


Izumi, Volume 8 No 2, 2019

e-ISSN: 2502-3535 p-ISSN: 2338-249X

Tersedia online di http://ejournal.undip.ac.id/index.php/izumi

soru (剃る) 'mencukur'

\begin{tabular}{|c|c|c|}
\hline & $\begin{array}{l}\text { 'X melakukan sesuatu pada } \\
\text { seseorang dalam waktu tertentu' }\end{array}$ & 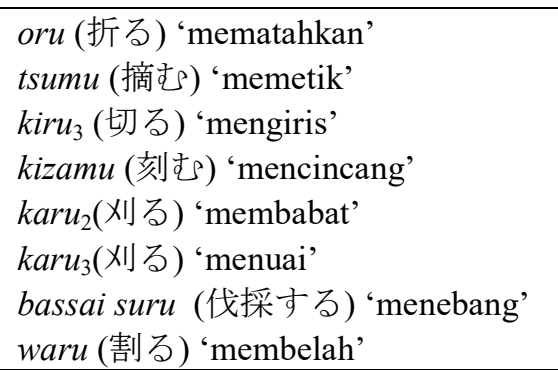 \\
\hline \multirow[t]{2}{*}{$\begin{array}{l}\text { 'X melakukan sesuatu pada } \\
\text { sesuatu' }\end{array}$} & $\begin{array}{l}\text { 'X melakukan sesuatu pada sesuatu } \\
\text { dengan sesuatu' }\end{array}$ & $\begin{array}{l}\text { yaburu (破る)'merobek' } \\
\text { saku (裂く) 'merobek' } \\
\text { kiru } \text { (切る) 'memotong' } \\
\text { tatsu (裁つ) 'memotong' } \\
\text { saidan suru (裁断する) 'memotong' }\end{array}$ \\
\hline & $\begin{array}{l}\text { 'X melakukan sesuatu pada sesuatu } \\
\text { dalam waktu tertentu' }\end{array}$ & $\begin{array}{l}\text { kiru }_{5} \text { (切る) 'menggergaji' } \\
\text { setsudan suru (切断する) 'memotong' }\end{array}$ \\
\hline
\end{tabular}

Makna dan Struktur Semantis Verba Kiru 'Potong'

Pada bagian ini adalah makna verba dan struktur semantis dari verba kiru 'potong'. Berikut penjelasannya.

\section{Makna Kiru 'penggal/tebas'}

Makna kiru 'penggal/tebas' merupakan makna prototipe dari kiru 1 (切る) 'menebas'/memenggal', kiru 2 (切る) 'menyayat', dan tosatsu suru (屠殺する) 'menyembelih'.Walaupun terletak pada ranah semantis yang sama, tetapi tiap verba memiliki perbedaan.

Berdasarkan contoh verba kiru (切る) 'menebas'/memenggal', mensyaratkan objek berupa leher pria, verba kiru (切 る) 'menyayat' mensyaratkan objek berupa tangan, sedangkan verba tosatsu suru (屠殺 する) 'menyembelih' mensyaratkan objek berupa lembu. Isi semantis ketiga verba ini memiliki perbedaan pada kombinasi antar komponen dalam mendeskripsikan makna setiap verba, untuk itu dilakukan parafrase makna seperti ilustrasi di bawah ini.

\section{$\boldsymbol{K i r u}_{1}$ (切る) 'memenggal'/'menebas'}

(a) seseorang (X) melakukan sesuatu pada bagian tubuh seseorang (Y) (leher pria) dengan sesuatu (Z) selama beberapa waktukarena ini sesuatu terjadi pada bagian tubuh (Y) seperti yang diinginkannya

(b) X melakukan sesuatu seperti ini ketika mereka melakukan sesuatu pada $\mathrm{Y}$

sebelumnya, mereka memikirkan hal seperti ini:

"Y harus mati seperti ini

"karena ini, aku ingin tubuh Y tidak utuh lagi

"aku ingin Y menjadi dua bagian tubuh yang terpisah

(c) ketika melakukan ini, X melakukannya dengan sesuatu yang tajam $(Z)$

$\mathrm{X}$ melakukan sesuatu seperti ini

(d) ketika X melakukan sesuatu dengan Z salah satu tangan $\mathrm{X}$ memegang sesuatu $\mathrm{Z}$ karena ini tangannya bergerak sesuai dengan keinginan $\mathrm{X}$

$\mathrm{Y}$ ini berpindah sesuai dengan keinginan $\mathrm{X}$

(e) ketika $X$ melakukan seperti ini pada $Y$ dengan $Z$ ujung yang tajam dari $\mathrm{Z}$ mengenai $\mathrm{Y}$

karena ini, ketika tangan $\mathrm{X}$ bergerak sesuai dengan keinginan $\mathrm{X}$

sesuatu terjadi pada bagian tubuh $\mathrm{Y}$ 
Izumi, Volume 8 No 2, 2019

e-ISSN: 2502-3535 p-ISSN: 2338-249X

Tersedia online di http://ejournal.undip.ac.id/index.php/izumi

(f) jika hal yang sama terjadi selama beberapa waktu setelah ini, dua bagian tubuh Y terpisah

$\boldsymbol{K i r u}_{2}$ (切る) 'menyayat'

(a) seseorang (X) melakukan sesuatu pada bagian tubuh seseorang $(\mathrm{Y})$ (tangan) dengan sesuatu $(\mathrm{Z})$ selama beberapa waktu

karena ini sesuatu terjadi pada bagian tubuh seseorang $(\mathrm{Y})$ seperti yang diinginkannya

(b) $\mathrm{X}$ melakukan sesuatu seperti ini ketika mereka melakukan sesuatu pada $\mathrm{Y}$

sebelumnya, mereka memikirkan hal seperti ini:

"Y harus mati seperti ini

"karena ini, aku ingin tubuh $\mathrm{Y}$ tidak utuh lagi

"aku ingin Y menjadi dua bagian tubuh yang tidak habis terpisah

(c) ketika melakukan ini, X melakukannya dengan sesuatu yang tajam $(Z)$

$X$ melakukan sesuatu seperti ini

(d) ketika $X$ melakukan sesuatu dengan $\mathrm{Z}$

salah satu tangan $X$ memegang $Z$

karena ini tangannya bergerak sesuai dengan keinginan $\mathrm{X}$

$\mathrm{Y}$ ini berpindah sesuai dengan keinginan $\mathrm{X}$

(e) ketika $\mathrm{X}$ melakukan seperti ini pada $\mathrm{Y}$ dengan $\mathrm{Z}$ ujung yang tajam dari $\mathrm{Z}$ mengenaiY

karena ini, ketika tangan $\mathrm{X}$ bergerak sesuai dengan keinginan $\mathrm{X}$ sesuatu terjadi pada bagian tubuh $\mathrm{Y}$

(f) jika hal yang sama terjadi selama beberapa waktu

setelah ini, Y tidak habis terpisah

\section{Tosatsu suru (屠殺する) 'menyembelih’}

(a) seseorang (X) melakukan sesuatu pada bagian tubuh dari seseorang (Y) (lembu) dengan sesuatu (Z) selama beberapa waktu

karena ini sesuatu terjadi pada bagian tubuh (Y) seperti yang diinginkannya

(b) $\mathrm{X}$ melakukan sesuatu seperti ini ketika mereka melakukan sesuatu pada $Y$

sebelumnya, mereka memikirkan hal seperti ini:

"Y harus mati seperti ini

"karena ini, aku ingin tubuh $\mathrm{Y}$ tidak utuh lagi

"aku ingin $\mathrm{Y}$ itu menjadi dua bagian tubuh yang tidak habis terpisah

(c) ketika melakukan ini, X melakukannya dengan sesuatu yang tajam $(Z)$

$X$ melakukan sesuatu seperti ini

(d) ketika X melakukan sesuatu dengan $Z$

salah satu tangan X memegang Z karena ini tangannya bergerak sesuai dengan keinginan $\mathrm{X}$

$\mathrm{Y}$ ini berpindah sesuai dengan keinginan $\mathrm{X}$

(e) ketika $X$ melakukan seperti ini pada $Y$ dengan $Z$ ujung yang tajam dari $\mathrm{Z}$ mengenai $\mathrm{Y}$

karena ini, ketika tangan $\mathrm{X}$ bergerak sesuai dengan keinginan $\mathrm{X}$

sesuatu terjadi pada bagian tubuh $\mathrm{Y}$

(f) jika hal yang sama terjadi selama beberapa waktu

setelah ini, Y tidak habis terpisah

Berdasarkan ilustrasi di atas, perbedaan verba kiru (切る) 'menebas'/'memenggal', verba kiru 2 (切る) 'menyayat' dan verba tosatsu suru (屠殺する) 'menyembelih' terletak pada komponen (a), (b), dan (f). Jika perbedaan komponen ini diabaikan, maka dihasilkan struktur sebagai berikut.

(a) seseorang (X) melakukan sesuatu pada bagian tubuh dari seseorang $(Y)[\ldots]$ dengan sesuatu $(\mathrm{Z})$ selama beberapa waktu

karena ini sesuatu terjadi pada bagian tubuh (Y) seperti yang diinginkannya

(b) $\mathrm{X}$ melakukan sesuatu seperti ini ketika mereka melakukan sesuatu pada $\mathrm{Y}$

sebelumnya, mereka memikirkan hal seperti ini:

"Y harus mati seperti ini

"karena ini, aku ingin tubuh Y tidak utuh lagi

"aku ingin $\mathrm{Y}$ itu menjadi $[\ldots]$

(c) ketika melakukan ini, $\mathrm{X}$ melakukannya dengan sesuatu yang tajam $(Z)$

$X$ melakukan sesuatu seperti ini

(d) ketika X melakukan sesuatu dengan $\mathrm{Z}$ salah satu tangan $\mathrm{X}$ memegang $\mathrm{Z}$

karena ini tangannya bergerak sesuai dengan keinginan $\mathrm{X}$

$\mathrm{Y}$ ini berpindah sesuai dengan keinginan $\mathrm{X}$

(e) ketika $X$ melakukan seperti ini pada $Y$ dengan $Z$ ujung yang tajam dari $\mathrm{Z}$ mengenai $\mathrm{Y}$

karena ini, ketika tangan $\mathrm{X}$ bergerak sesuai dengan keinginan $\mathrm{X}$

sesuatu terjadi pada bagian tubuh $\mathrm{Y}$

(f) jika hal yang sama terjadi selama beberapa waktu

setelah ini, Y $[\ldots]$ 


\section{Makna Sanpatsu Suru 'pangkas'}

Makna kiru 'penggal/tebas' merupakan makna prototipe dari sanpatsu suru (散髮す る ) 'memangkas', karu 1 ( 刈 る) 'memangkas', dan soru (剃 る) 'mencukur'.Walaupun terletak pada ranah semantis yang sama, tetapi tiap verba memiliki perbedaan.Untuk lebih jelasnya dapat dilihat pada contoh verba berikut ini.

Berdasarkan contoh verba sanpatsu suru (散髮する) 'memangkas' mensyaratkan objek yang kecil berupa rambut, verba karu $_{1}$ (XI る) 'memangkas' mensyaratkan objek yang kecil berupa rambut, sedangkan verba soru (剃る) 'mencukur' mensyaratkan objek yang kecil berupa kumis. Isi semantis ketiga verba ini memiliki perbedaanpada kombinasi antar komponen dalam mendeskripsikan makna setiap verba, untuk itu dilakukan parafrase makna seperti ilustrasi di bawah ini.

\section{Sanpatsu suru (散髮する) 'memangkas'}

(a) seseorang (X) melakukan sesuatu pada bagian tubuh seseorang $(\mathrm{Y})$ (rambut) dengan sesuatu $(\mathrm{Z})$ selama beberapa waktu

karena ini sesuatu terjadi pada bagian tubuh seseorang $(\mathrm{Y})$ seperti yang diinginkannya

(b) $\mathrm{X}$ melakukan sesuatu seperti ini ketika mereka melakukan sesuatu pada $\mathrm{Y}$ sebelumnya, mereka memikirkan hal seperti ini: "Y harus terpotong seperti ini

"karena ini, aku ingin Y menjadi pendek atau habis

(c) ketika melakukan ini, X melakukannya dengan sesuatu yang tajam $(Z)$

$X$ melakukan sesuatu seperti ini

(d) ketika X melakukan sesuatu dengan $\mathrm{Z}$ salah satu tangan $\mathrm{X}$ memegang $\mathrm{Z}$

karena ini tangannya bergerak sesuai dengan keinginan $\mathrm{X}$

$\mathrm{Y}$ ini berpindah sesuai dengan keinginan $\mathrm{X}$

(e) ketika $X$ melakukan seperti ini pada $Y$ dengan $Z$ ujung yang tajam dari $\mathrm{Z}$ mengenai $\mathrm{Y}$ karena ini, ketika tangan $\mathrm{X}$ bergerak sesuai dengan keinginan $X$

sesuatu terjadi pada bagian tubuh Y

(f) jika hal yang sama terjadi selama beberapa waktu

setelah ini, Y pendek atau habis

$\boldsymbol{K a r u}_{1}$ (刚る) 'memangkas'

(a) seseorang (X) melakukan sesuatu pada bagian tubuh seseorang (Y) (bulu domba) dengan sesuatu (Z) selama beberapa waktu

karena ini sesuatu terjadi pada bagian tubuh seseorang $(\mathrm{Y})$ seperti yang diinginkannya

(b) $\mathrm{X}$ melakukan sesuatu seperti ini ketika mereka melakukan sesuatu pada $\mathrm{Y}$

sebelumnya, mereka memikirkan hal seperti ini:

"Y harus terpotong seperti ini

"karena ini, aku ingin Y menjadi habis

(c) ketika melakukan ini, $\mathrm{X}$ melakukannya dengan sesuatu yang tajam $(\mathrm{Z})$

X melakukan sesuatu seperti ini

(d) ketika X melakukan sesuatu dengan Z

salah satu tangan $\mathrm{X}$ memegang $\mathrm{Z}$

karena ini tangannya bergerak sesuai dengan keinginan $\mathrm{X}$

$\mathrm{Y}$ ini berpindah sesuai dengan keinginan $\mathrm{X}$

(e) ketika $\mathrm{X}$ melakukan seperti ini pada $\mathrm{Y}$ dengan $\mathrm{Z}$ ujung yang tajam dari $\mathrm{Z}$ mengenai $\mathrm{Y}$

karena ini, ketika tangan $\mathrm{X}$ bergerak sesuai dengan keinginan $X$

sesuatu terjadi pada bagian tubuh $\mathrm{Y}$

(f) jika hal yang sama terjadi selama beberapa waktu

setelah ini, Y habis

Soru (剃る) 'mencukur'

(a) seseorang (X) melakukan sesuatu pada bagian tubuh seseorang (Y) (KUMIS) dengan sesuatu (Z) selama beberapa waktu

karena ini sesuatu terjadi pada bagian tubuh seseorang (Y) seperti yang diinginkannya

(b) $\mathrm{X}$ melakukan sesuatu seperti ini ketika mereka melakukan sesuatu pada $\mathrm{Y}$

sebelumnya, mereka memikirkan hal seperti ini:

"Y harus terpotong seperti ini

"karena ini, aku ingin Y menjadi rapi atau habis

(c) ketika melakukan ini, $\mathrm{X}$ melakukannya dengan sesuatu yang tajam $(Z)$ 
Izumi, Volume 8 No 2, 2019

e-ISSN: 2502-3535 p-ISSN: 2338-249X

Tersedia online di http://ejournal.undip.ac.id/index.php/izumi

$\mathrm{X}$ melakukan sesuatu seperti ini

(d) ketika X melakukan sesuatu dengan Z

salah satu tangan $\mathrm{X}$ memegang $\mathrm{Z}$

karena ini tangannya bergerak sesuai dengan keinginan $\mathrm{X}$

$\mathrm{Y}$ ini berpindah sesuai dengan keinginan $\mathrm{X}$

(e) ketika $X$ melakukan seperti ini pada $Y$ dengan $Z$ ujung yang tajam dari $\mathrm{Z}$ mengenaiY

karena ini, ketika tangan $\mathrm{X}$ bergerak sesuai dengan keinginan $\mathrm{X}$ sesuatu terjadi pada bagian tubuh $\mathrm{Y}$

(f) jika hal yang sama terjadi selama beberapa waktu

setelah ini, Y rapi atau habis

Berdasarkan ilustrasi di atas, perbedaan verba sanpatsu suru (散髮する) 'memangkas', verba karu 1 ( 刈 る) 'memangkas', dan verba soru (剃る) 'mencukur'terletak pada komponen (a), (b), dan (f). Jika perbedaan komponen ini diabaikan, maka dihasilkan struktur sebagai berikut.

(a) seseorang (X) melakukan sesuatu pada bagian tubuh seseorang (Y) [...] dengan sesuatu (Z) selama beberapa waktu

karena ini sesuatu terjadi pada bagian tubuh seseorang $(\mathrm{Y})$ seperti yang diinginkannya

(b) $\mathrm{X}$ melakukan sesuatu seperti ini ketika mereka melakukan sesuatu pada Y

sebelumnya, mereka memikirkan hal seperti ini:

"Y harus terpotong seperti ini

"karena ini, aku ingin Y menjadi [...]

(c) ketika melakukan ini, $\mathrm{X}$ melakukannya dengan sesuatu yang tajam $(Z)$

$\mathrm{X}$ melakukan sesuatu seperti ini

(d) ketika X melakukan sesuatu dengan $Z$

salah satu tangan $\mathrm{X}$ memegang $\mathrm{Z}$

karena ini tangannya bergerak sesuai dengan keinginan $\mathrm{X}$

$Y$ ini berpindah sesuai dengan keinginan $X$

(e) ketika $\mathrm{X}$ melakukan seperti ini pada $\mathrm{Y}$ dengan $\mathrm{Z}$ ujung yang tajam dari $\mathrm{Z}$ mengenaiY

karena ini, ketika tangan $\mathrm{X}$ bergerak sesuai dengan keinginan $\mathrm{X}$

sesuatu terjadi pada bagian tubuh $\mathrm{Y}$

(f) jika hal yang sama terjadi selama beberapa waktu

setelah ini, Y $[\ldots]$

\section{Makna Oru 'patah'}

Makna oru 'patah' merupakan makna prototipe dari oru (折る) 'mematahkan' dan tsumu (抓む) 'memetik'.Walaupun terletak pada ranah semantis yang sama, tetapi tiap verba memiliki perbedaan. Untuk lebih jelasnya dapat dilihat pada contoh verba berikut ini.

Berdasarkan contoh verba oru (折る) 'mematahkan' mensyaratkan objek yang kecil berupa ranting pohon dan kata sifat cepat. Sedangkan verba tsumu (抓む) 'memetik' mensyaratkan objek yang kecil berupa bunga dan kata sifat cepat Isi semantis ketiga verba ini memiliki perbedaanpada kombinasi antar komponen dalam mendeskripsikan makna setiap verba, untuk itu dilakukan parafrase makna seperti ilustrasi di bawah ini.

\section{Oru (折る) 'mematahkan'}

(a) seseorang (X) melakukan sesuatu pada bagian tubuh seseorang (Y) (RANTING POHON) dengan sesuatu $(\mathrm{Z})$ selama beberapa waktu karena ini sesuatu terjadi pada bagian tubuh seseorang (Y) seperti yang diinginkannya

(b) $\mathrm{X}$ melakukan sesuatu seperti ini ketika mereka melakukan sesuatu pada Y sebelumnya, mereka memikirkan hal seperti ini: "Y harus terpotong seperti ini

"karena ini, aku ingin Y menjadi terpisah dari akarnya

(c) ketika melakukan seperti ini, X melakukannya dengan sesuatu yang merupakan bagian tubuh seseorang $(Z)$

$\mathrm{X}$ melakukan sesuatu seperti ini

(d) ketika X melakukan sesuatu dengan Z kedua tangan $\mathrm{X}$ bergerak dengan cepat sesuai dengan keinginan $\mathrm{X}$ $\mathrm{Y}$ ini berpindah sesuai dengan keinginan $\mathrm{X}$

(e) ketika $X$ melakukan seperti ini pada $Y$ dengan $Z$ kedua tangan $(\mathrm{Z})$ memegang $\mathrm{Y}$

karena ini, ketika tangan $\mathrm{X}$ bergerak sesuai dengan keinginan $\mathrm{X}$ sesuatu terjadi pada bagian tubuh $\mathrm{Y}$

(f) jika hal yang sama terjadi selama beberapa waktu

setelah ini, Y terpisah dari akarnya 


\section{Tsumu (抓む) 'memetik'}

(a) seseorang (X) melakukan sesuatu pada bagian tubuh seseorang (Y) (bunga) dengan sesuatu (Z) untuk beberapa waktu

karena ini sesuatu terjadi pada bagian tubuh seseorang $(\mathrm{Y})$ seperti yang diinginkannya

(b) $\mathrm{X}$ melakukan sesuatu seperti ini ketika mereka melakukan sesuatu pada $Y$

sebelumnya, mereka memikirkan hal seperti ini:

"Y harus terpotong seperti ini

"karena ini, aku ingin Y menjadi terpisah dari batangnya

(c) ketika melakukan seperti ini, X melakukannya dengan sesuatu yang merupakan bagian tubuh seseorang $(Z)$

$X$ melakukan sesuatu seperti ini

(d) ketika X melakukan sesuatu dengan Z

kedua tangan $\mathrm{X}$ bergerak dengan cepat sesuai dengan keinginan $X$

$\mathrm{Y}$ ini berpindah sesuai dengan keinginan $\mathrm{X}$

(e) ketika $X$ melakukan seperti ini pada $Y$ dengan $Z$ kedua tangan $(\mathrm{Z})$ memegang $\mathrm{Y}$

karena ini, ketika tangan $\mathrm{X}$ bergerak sesuai dengan keinginan $\mathrm{X}$

sesuatu terjadi pada bagian tubuh $\mathrm{Y}$

(f) jika hal yang sama terjadi selama beberapa waktu setelah ini, Y terpisah dari batangnya

Berdasarkan ilustrasi di atas, perbedaan verba oru (折る) 'mematahkan' dan verba tsumu (抓む) 'memetik'terletak pada komponen (a), (b) dan (f). Jika perbedaan komponen ini diabaikan, maka dihasilkan struktur sebagai berikut.

(a) seseorang $(\mathrm{X})$ melakukan sesuatu pada bagian tubuh seseorang $(\mathrm{Y})[\ldots]$ dengan sesuatu $(\mathrm{Z})$ selama beberapa waktu

karena ini sesuatu terjadi pada bagian tubuh seseorang $(\mathrm{Y})$ seperti yang diinginkannya

(b) $\mathrm{X}$ melakukan sesuatu seperti ini ketika mereka melakukan sesuatu pada $\mathrm{Y}$

sebelumnya, mereka memikirkan hal seperti ini:

"Y harus terpotong seperti ini

"karena ini, aku ingin Y menjadi [...]

(c) ketika melakukan seperti ini, $\mathrm{X}$ melakukannya dengan sesuatu yang merupakan bagian tubuh seseorang $(Z)$

$X$ melakukan sesuatu seperti ini

(d) ketika X melakukan sesuatu dengan Z kedua tangan $\mathrm{X}$ bergerak dengan cepat sesuai dengan keinginan $X$

$Y$ ini berpindah sesuai dengan keinginan $X$

(e) ketika $\mathrm{X}$ melakukan seperti ini pada $\mathrm{Y}$ dengan $\mathrm{Z}$ kedua tangan $(\mathrm{Z})$ memegang $\mathrm{Y}$

karena ini, ketika tangan $\mathrm{X}$ bergerak sesuai dengan keinginan $X$

sesuatu terjadi pada bagian tubuh $\mathrm{Y}$

(f) jika hal yang sama terjadi selama beberapa waktu

setelah ini, Y $[\ldots]$

\section{Makna Kiru 'iris}

Makna kiru 'iris' merupakan makna prototipe dari $\mathrm{Kiru}_{3}$ (切る) 'mengiris' dan kizamu (刻む) 'mencincang'.Walaupun terletak pada ranah semantis yang sama, tetapi tiap verba memiliki perbedaan.Untuk lebih jelasnya dapat dilihat pada contoh verba berikut ini.

Berdasarkan contoh verba kiru 3 (切る) 'mengiris' mensyaratkan objek yang kecil berupa daun bawang dan kata sifat cepat, sedangkan verba kizamu (刻むs) 'mencincang' mensyaratkan objek yang kecil berupa bawang putih dan kata sifat cepat. Isi semantis ketiga verba ini memiliki perbedaanpada kombinasi antar komponen dalam mendeskripsikan makna setiap verba, untuk itu dilakukan parafrase makna seperti ilustrasi di bawah ini.

\section{$\mathrm{Kiru}_{3}$ (切る) 'mengiris'}

(a) seseorang (X) melakukan sesuatu pada bagian tubuh seseorang (Y) (DAUN BAWANG) dengan sesuatu (Z) selama beberapa waktu karena ini sesuatu terjadi pada seseorang (Y) seperti yang diinginkannya

(b) X melakukan sesuatu seperti ini ketika mereka melakukan sesuatu pada $\mathrm{Y}$ sebelumnya, mereka memikirkan hal seperti ini:

"Y harus terpotong seperti ini "karena ini, aku ingin Y menjadi beberapa bagian yang tipis-tipis

(c) ketika melakukan seperti ini, X melakukannya dengan sesuatu yang tajam $(\mathrm{Z})$

$\mathrm{X}$ melakukan sesuatu seperti ini 
Izumi, Volume 8 No 2, 2019

e-ISSN: 2502-3535 p-ISSN: 2338-249X

Tersedia online di http://ejournal.undip.ac.id/index.php/izumi

(d) ketika X melakukan sesuatu dengan Z

salah satu tangan $\mathrm{X}$ memegang $\mathrm{Z}$

karena ini tangannya bergerak dengan cepat sesuai dengan keinginan $X$

$\mathrm{Y}$ ini berpindah sesuai dengan keinginan $\mathrm{X}$

(e) ketika $X$ melakukan seperti ini pada $Y$ dengan $Z$ ujung yang tajam dari $\mathrm{Z}$ mengenaiY

karena ini, ketika tangan $\mathrm{X}$ bergerak sesuai dengan keinginan $\mathrm{X}$

sesuatu terjadi pada bagian tubuh $Y$

(f) jika hal yang sama terjadi selama beberapa waktu

setelah ini, Y menjadi tipis-tipis

Kizamu (刻む) 'mencincang'

(a) seseorang (X) melakukan sesuatu pada bagian tubuh seseorang (Y) (bawang putih) dengan sesuatu (Z) selama beberapa waktu

karena ini sesuatu terjadi pada seseorang (Y) seperti yang diinginkannya

(b) X melakukan sesuatu seperti ini ketika mereka melakukan sesuatu pada $Y$

sebelumnya, mereka memikirkan hal seperti ini:

"Y harus terpotong seperti ini

"karena ini, aku ingin Y menjadi beberapa bagian yang kecil-kecil

(c) ketika melakukan seperti ini, X melakukannya dengan sesuatu yang tajam $(Z)$

$X$ melakukan sesuatu seperti ini

(d) ketika $X$ melakukan sesuatu dengan $Z$ salah satu tangan $\mathrm{X}$ memegang $\mathrm{Z}$

karena ini tangannya bergerak dengan cepat sesuai dengan keinginan $\mathrm{X}$

$\mathrm{Y}$ ini berpindah sesuai dengan keinginan $\mathrm{X}$

(e) ketika $X$ melakukan seperti ini pada $Y$ dengan $Z$ ujung yang tajam dari $\mathrm{Z}$ mengenai $\mathrm{Y}$

karena ini, ketika tangan $\mathrm{X}$ bergerak sesuai dengan keinginan $\mathrm{X}$

sesuatu terjadi pada bagian tubuh $\mathrm{Y}$

(f) jika hal yang sama terjadi selama beberapa waktu

setelah ini, Y menjadi kecil-kecil

Berdasarkan ilustrasi di atas, perbedaan verba kiru $_{3}$ (切る) 'mengiris', dan verba kizamu (刻む) 'mencincang'terletak pada komponen (a), (b), dan (f). Jika perbedaan komponen ini diabaikan, maka dihasilkan struktur sebagai berikut. (a) seseorang (X) melakukan sesuatu pada bagian tubuh seseorang $(\mathrm{Y})[\ldots]$ dengan sesuatu $(\mathrm{Z})$ selama beberapa waktu

karena ini sesuatu terjadi pada seseorang (Y) seperti yang diinginkannya

(b) $\mathrm{X}$ melakukan sesuatu seperti ini ketika mereka melakukan sesuatu pada $\mathrm{Y}$ sebelumnya, mereka memikirkan hal seperti ini:

"Y harus terpotong seperti ini

"karena ini, aku ingin Y menjadi [...]

(c) ketika melakukan seperti ini, $\mathrm{X}$ melakukannya dengan sesuatu yang tajam $(Z)$

$\mathrm{X}$ melakukan sesuatu seperti ini

(d) ketika X melakukan sesuatu dengan Z

salah satu tangan $\mathrm{X}$ memegang $\mathrm{Z}$

karena ini tangannya bergerak dengan cepat sesuai dengan keinginan $\mathrm{X}$

$\mathrm{Y}$ ini berpindah sesuai dengan keinginan $\mathrm{X}$

(e) ketika $X$ melakukan seperti ini pada $Y$ dengan $Z$ ujung yang tajam dari $\mathrm{Z}$ mengenai $\mathrm{Y}$

karena ini, ketika tangan $\mathrm{X}$ bergerak sesuai dengan keinginan $\mathrm{X}$

sesuatu terjadi pada bagian tubuh $\mathrm{Y}$

(f) jika hal yang sama terjadi selama beberapa waktu

setelah ini, Y menjadi $[\ldots]$

\section{Makna Karu 'babat'}

Makna karu 'babat' merupakan makna prototipe dari karu $_{2}$ (刘る) 'membabat' dan $\mathrm{karu}_{3}$ (XIJ) 'menuai'.Walaupun terletak pada ranah semantis yang sama, tetapi tiap verba memiliki perbedaan.Untuk lebih jelasnya dapat dilihat pada contoh verba berikut ini.

Berdasarkan contoh verba karu $_{2}$ (刚る) 'membabat' mensyaratkan objek yang kecil berupa rumput dan kata sifat cepat, sedangkan verba karu $_{3}\left(x_{刂}\right.$ る ) 'menuai'mensyaratkan objek yang kecil berupa padi dan kata sifat cepat. Isi semantis ketiga verba ini memiliki perbedaanpada kombinasi antar komponen dalam mendeskripsikan makna setiap verba, untuk itu dilakukan parafrase makna seperti ilustrasi di bawah ini. 
$\boldsymbol{K a r u}_{2}$ (刚る) 'membabat'

(a) seseorang (X) melakukan sesuatu pada bagian tubuh seseorang $(\mathrm{Y})$ (rumput) dengan sesuatu $(\mathrm{Z})$ selama beberapa waktu

karena ini sesuatu terjadi pada bagian tubuh seseorang(Y) seperti yang diinginkannya

(b) $\mathrm{X}$ melakukan sesuatu seperti ini ketika mereka melakukan sesuatu pada $Y$

sebelumnya, mereka memikirkan hal seperti ini:

"Y harus terpotong seperti ini

"karena ini, aku ingin Y menjadi terpotong habis

(c) ketika melakukan seperti ini, $\mathrm{X}$ melakukannya dengan sesuatu yang tajam $(Z)$

$X$ melakukan sesuatu seperti ini

(d) ketika X melakukan sesuatu dengan $Z$

salah satu tangan $\mathrm{X}$ memegang $\mathrm{Z}$

karena ini tangannya bergerak dengan cepat sesuai dengan keinginan $\mathrm{X}$

$\mathrm{Y}$ ini berpindah sesuai dengan keinginan $\mathrm{X}$

(e) ketika $X$ melakukan seperti ini pada $Y$ dengan $Z$ ujung yang tajam dari $\mathrm{Z}$ mengenai $\mathrm{Y}$

karena ini, ketika tangan $\mathrm{X}$ bergerak sesuai dengan keinginan $\mathrm{X}$

sesuatu terjadi pada bagian tubuh $\mathrm{Y}$

(f) jika hal yang sama terjadi selama beberapa waktu

setelah ini, Y menjadi habis

$\boldsymbol{K a r u}_{3}$ (刚る) 'menuai'

(a) seseorang (X) melakukan sesuatu pada bagian tubuh seseorang $(\mathrm{Y})$ (padi) dengan sesuatu $(\mathrm{Z})$ selama beberapa waktu

karena ini sesuatu terjadi pada seseorang(Y) seperti yang diinginkannya

(b) $\mathrm{X}$ melakukan sesuatu seperti ini ketika mereka melakukan sesuatu pada $Y$

sebelumnya, mereka memikirkan hal seperti ini:

"Y harus terpotong seperti ini

"karena ini, aku ingin Y menjadi terpotong pada batangnya

(c) ketika melakukan seperti ini, X melakukannya dengan sesuatu yang tajam $(Z)$

$X$ melakukan sesuatu seperti ini

(d) ketika X melakukan sesuatu dengan Z

salah satu tangan $\mathrm{X}$ memegang $\mathrm{Z}$

karena ini tangannya bergerak dengan cepat sesuai dengan keinginan $\mathrm{X}$

$\mathrm{Y}$ ini berpindah sesuai dengan keinginan $\mathrm{X}$

(e) ketika $X$ melakukan seperti ini pada $Y$ dengan $Z$ ujung yang tajam dari $\mathrm{Z}$ mengenaiY karena ini, ketika tangan $\mathrm{X}$ bergerak sesuai dengan keinginan $X$

sesuatu terjadi pada bagian tubuh $Y$

(f) jika hal yang sama terjadi selama beberapa waktu

setelah ini, Y menjadi terpotong batangnya

Berdasarkan ilustrasi di atas, perbedaan verba karu $_{2}$ (刚る) 'membabat' dan verba karu $_{3}$ ( 刏 る ) 'menuai'terletak pada komponen (a), (b), dan (f). Jika perbedaan komponen ini diabaikan, maka dihasilkan struktur sebagai berikut.

(a) seseorang (X) melakukan sesuatu pada bagian tubuh seseorang $(\mathrm{Y})[\ldots]$ dengan sesuatu $(\mathrm{Z})$ selama beberapa waktu

karena ini sesuatu terjadi pada seseorang $(\mathrm{Y})$ seperti yang diinginkannya

(b) X melakukan sesuatu seperti ini ketika mereka melakukan sesuatu pada $\mathrm{Y}$

sebelumnya, mereka memikirkan hal seperti ini:

"Y harus terpotong seperti ini

"karena ini, aku ingin Y menjadi [...]

(c) ketika melakukan seperti ini, $\mathrm{X}$ melakukannya dengan sesuatu yang tajam $(\mathrm{Z})$

$\mathrm{X}$ melakukan sesuatu seperti ini

(d) ketika X melakukan sesuatu dengan Z

salah satu tangan $\mathrm{X}$ memegang $\mathrm{Z}$

karena ini tangannya bergerak dengan cepat sesuai dengan keinginan $\mathrm{X}$

$\mathrm{Y}$ ini berpindah sesuai dengan keinginan $\mathrm{X}$

(e) ketika $X$ melakukan seperti ini pada $Y$ dengan $Z$ ujung yang tajam dari $\mathrm{Z}$ mengenaiY

karena ini, ketika tangan $\mathrm{X}$ bergerak sesuai dengan keinginan $X$

sesuatu terjadi pada bagian tubuh $Y$

(f) jika hal yang sama terjadi selama beberapa waktu

setelah ini, Y menjadi $[\ldots]$

\section{Makna Bassai Suru 'tebang'}

Makna bassai suru 'tebang' merupakan makna prototipe dari waru (割 る) 'membelah' dan bassai suru (伐採する) 'menebang'. Walaupun terletak pada ranah semantis yang sama, tetapi tiap verba memiliki perbedaan.Untuk lebih jelasnya dapat dilihat pada contoh verba berikut ini. 
Izumi, Volume 8 No 2, 2019

e-ISSN: 2502-3535 p-ISSN: 2338-249X

Tersedia online di http://ejournal.undip.ac.id/index.php/izumi

Berdasarkan contoh verba bassai suru (伐採する) 'menebang' mensyaratkan objek yang besar berupa pohon besar dan kata sifat perlahan, sedangkan verba waru (割 る) 'membelah' mensyaratkan objek yang besar berupa pohon dan kata sifat cepat. Isi semantis ketiga verba ini memiliki perbedaanpada kombinasi antar komponen dalam mendeskripsikan makna setiap verba, untuk itu dilakukan parafrase makna seperti ilustrasi di bawah ini.

\section{Bassai suru(伐採する) 'menebang’}

(a) seseorang $(\mathrm{X})$ melakukan sesuatu pada bagian tubuh dari seseorang $(\mathrm{Y})$ (pohon besar) dengan sesuatu (Z) selama beberapa waktu karena ini sesuatu terjadi pada seseorang(Y) seperti yang diinginkannya

(b) $\mathrm{X}$ melakukan sesuatu seperti ini ketika mereka melakukan sesuatu pada $\mathrm{Y}$ sebelumnya, mereka memikirkan hal seperti ini: "Y harus terpotong seperti ini "karena ini, aku ingin $\mathrm{Y}$ menjadi terpisah dari akarnya

(c) ketika melakukan seperti ini, X melakukannya dengan sesuatu yang tajam $(\mathrm{Z})$

$\mathrm{X}$ melakukan sesuatu seperti ini

(d) ketika X melakukan sesuatu dengan Z salah satu tangan X memegang Z karena ini tangannya bergerak dengan perlahan sesuai dengan keinginan $\mathrm{X}$

$\mathrm{Y}$ ini berpindah sesuai dengan keinginan $\mathrm{X}$

(e) ketika $X$ melakukan seperti ini pada $Y$ dengan $Z$ ujung yang tajam dari $\mathrm{Z}$ mengenai $\mathrm{Y}$ karena ini, ketika tangan $\mathrm{X}$ bergerak sesuai dengan keinginan $X$ sesuatu terjadi pada bagian tubuh $\mathrm{Y}$

(f) jika hal yang sama terjadi selama beberapa waktu

setelah ini, Y terpisah akarnya

\section{Waru (割る) ‘membelah’}

(a) seseorang (X) melakukan sesuatu pada bagian tubuh dari seseorang $(\mathrm{Y})$ (pohon) dengan sesuatu (Z) selama beberapa waktu karena ini sesuatu terjadi pada seseorang(Y) seperti yang diinginkannya (b) X melakukan sesuatu seperti ini ketika mereka melakukan sesuatu pada $\mathrm{Y}$ sebelumnya, mereka memikirkan hal seperti ini: "Y harus terpotong seperti ini "karena ini, aku ingin $\mathrm{Y}$ menjadi terbelah menjadi bagian kecil

(c) ketika melakukan seperti ini, X melakukannya dengan sesuatu yang tajam $(Z)$

$\mathrm{X}$ melakukan sesuatu seperti ini

(d) ketika X melakukan sesuatu dengan Z salah satu tangan $\mathrm{X}$ memegang $\mathrm{Z}$

karena ini tangannya bergerak dengan cepat sesuai dengan keinginan $X$

$\mathrm{Y}$ ini berpindah sesuai dengan keinginan $\mathrm{X}$

(e) ketika $\mathrm{X}$ melakukan seperti ini pada $\mathrm{Y}$ dengan $\mathrm{Z}$ ujung yang tajam dari $\mathrm{Z}$ mengenai $\mathrm{Y}$

karena ini, ketika tangan $\mathrm{X}$ bergerak sesuai keinginan $\mathrm{X}$ sesuatu terjadi pada bagian tubuh $\mathrm{Y}$

(f) jika hal yang sama terjadi selama beberapa waktu

setelah ini, Y terbelah menjadi kecil

Berdasarkan ilustrasi di atas, perbedaan verba bassai suru (伐採する) 'menebang'dan verba waru (割 る) 'membelah' terletak pada komponen (a), (b), (d) dan (f). Jika perbedaan komponen ini diabaikan, maka dihasilkan struktur sebagai berikut.

(a) seseorang (X) melakukan sesuatu pada bagian tubuh dari seseorang $(\mathrm{Y})[\ldots]$ dengan sesuatu $(\mathrm{Z})$ selama beberapa waktu

karena ini sesuatu terjadi pada seseorang(Y) seperti yang diinginkannya

(b) $\mathrm{X}$ melakukan sesuatu seperti ini ketika mereka melakukan sesuatu pada $Y$

sebelumnya, mereka memikirkan hal seperti ini:

"Y harus terpotong seperti ini

"karena ini, aku ingin Y menjadi [...]

(c) ketika melakukan seperti ini, X melakukannya dengan sesuatu yang tajam $(\mathrm{Z})$

$X$ melakukan sesuatu seperti ini

(d) ketika X melakukan sesuatu dengan Z

salah satu tangan $\mathrm{X}$ memegang $\mathrm{Z}$

karena ini tangannya bergerak [...] sesuai dengan keinginan $X$

$\mathrm{Y}$ ini berpindah sesuai dengan keinginan $\mathrm{X}$

(e) ketika $X$ melakukan seperti ini pada $Y$ dengan $Z$ ujung yang tajam dari $\mathrm{Z}$ mengenai $\mathrm{Y}$

karena ini, ketika tangan $\mathrm{X}$ bergerak sesuai keinginan X 
sesuatu terjadi pada bagian tubuh $\mathrm{Y}$

(f) jika hal yang sama terjadi selama beberapa waktu

setelah ini, Y $[\ldots]$

\section{Makna yaburu 'robek'}

Makna yaburu 'robek' merupakan makna prototipe dari yaburu (破る) 'merobek' dan saku ( 裂 <) 'merobek'.Walaupun terletak pada ranah semantis yang sama, tetapi tiap verba memiliki perbedaan.Untuk lebih jelasnya dapat dilihat pada contoh verba berikut ini.

Berdasarkan contoh verbayaburu (破る) 'merobek' mensyaratkan objek yang kecil berupa kertas, sedangkan verba saku (裂く) 'merobek' mensyaratkan objek berupa jeans. Isi semantis ketiga verba ini memiliki perbedaanpada kombinasi antar komponen dalam mendeskripsikan makna setiap verba, untuk itu dilakukan parafrase makna seperti ilustrasi di bawah ini.

\section{Yaburu (破る) 'merobek’}

(a) seseorang (X) melakukan sesuatu pada sesuatu (Y) (kertas) dengan sesuatu (Z) selama beberapa waktu

karena ini sesuatu terjadi pada sesuatu (Y) seperti yang diinginkannya

(b) $\mathrm{X}$ melakukan sesuatu seperti ini ketika mereka melakukan sesuatu pada Y

sebelumnya, mereka memikirkan hal seperti ini:

"Y harus terpotong seperti ini

"karena ini, aku ingin Y menjadi terpisah beberapa bagian

(c) ketika melakukan seperti ini, X melakukannya dengan sesuatu yang merupakan bagian tubuh seseorang $(Z)$

(d) ketika $\mathrm{X}$ melakukan sesuatu dengan $\mathrm{Z}$

kedua tangan $\mathrm{X}$ bergerak sesuai dengan keinginan $\mathrm{X}$

$\mathrm{Y}$ ini berpindah sesuai dengan keinginan $\mathrm{X}$

(e) ketika $X$ melakukan seperti ini pada $Y$ dengan $Z$ kedua tangan $\mathrm{Z}$ mengenai $\mathrm{Y}$

karena ini, ketika tangan $\mathrm{X}$ bergerak sesuai dengan keinginan $\mathrm{X}$

sesuatu terjadi pada $\mathrm{Y}$ (f) jika hal yang sama terjadi selama beberapa waktu setelah ini, Y terpisah beberapa bagian

Saku (裂 $<) ~ ' m e r o b e k '$

(a) seseorang (X) melakukan sesuatu pada sesuatu (Y) (JEANS) dengan sesuatu (Z) selama beberapa waktu

karena ini sesuatu terjadi pada sesuatu (Y) seperti yangdiinginkannya

(b) $\mathrm{X}$ melakukan sesuatu seperti ini ketika mereka melakukan sesuatu pada Y

sebelumnya, mereka memikirkan hal seperti ini:

"Y harus terpotong seperti ini

"karena ini, aku ingin Y menjadi terpisah beberapa bagian

(c) ketika melakukan seperti ini, X melakukannya dengan sesuatu yang tajam $(Z)$

$\mathrm{X}$ melakukan sesuatu seperti ini

(d) ketika X melakukan sesuatu dengan Z

salah satu tangan $\mathrm{X}$ memegang $\mathrm{Z}$

karena ini tangannya bergerak sesuai dengan keinginan $\mathrm{X}$

$\mathrm{Y}$ ini berpindah sesuai dengan keinginan $\mathrm{X}$

(e) ketika $X$ melakukan seperti ini pada $Y$ dengan $Z$ ujung yang tajam dari $\mathrm{Z}$ mengenai $\mathrm{Y}$

karena ini, ketika tangan $\mathrm{X}$ bergerak sesuai dengan keinginan $\mathrm{X}$

sesuatu terjadi pada $\mathrm{Y}$

(f) jika hal yang sama terjadi selama beberapa waktu

setelah ini, Y terpisah beberapa bagian

Berdasarkan ilustrasi di atas, perbedaan verba yaburu (破る) 'merobek' dan verba saku ( 裂く) 'merobek'terletak pada komponen (a), (c), (d), dan (e). Jika perbedaan komponen ini diabaikan, maka dihasilkan struktur sebagai berikut.

(a) seseorang (X) melakukan sesuatu pada sesuatu (Y) [...] dengan sesuatu (Z) selama beberapa waktu

karena ini sesuatu terjadi pada sesuatu (Y) seperti yangdiinginkannya

(b) $\mathrm{X}$ melakukan sesuatu seperti ini ketika mereka melakukan sesuatu pada Y sebelumnya, mereka memikirkan hal seperti ini: "Y harus terpotong seperti ini 
Izumi, Volume 8 No 2, 2019

e-ISSN: 2502-3535 p-ISSN: 2338-249X

Tersedia online di http://ejournal.undip.ac.id/index.php/izumi

"karena ini, aku ingin Y menjadi terpisah beberapa bagian

(c) ketika melakukan seperti ini, X melakukannya dengan sesuatu $[\ldots](\mathrm{Z})$

$\mathrm{X}$ melakukan sesuatu seperti ini

(d) ketika $\mathrm{X}$ melakukan sesuatu dengan $\mathrm{Z}$ [...] X memegang Z karena ini tangannya bergerak sesuai dengan keinginan $\mathrm{X}$

$\mathrm{Y}$ ini berpindah sesuai dengan keinginan $\mathrm{X}$

(e) ketika $X$ melakukan seperti ini pada $Y$ dengan $Z$ [...] dari $\mathrm{Z}$ mengenai $\mathrm{Y}$

karena ini, ketika tangan $\mathrm{X}$ bergerak sesuai dengan keinginan $\mathrm{X}$ sesuatu terjadi pada $\mathrm{Y}$

(f) jika hal yang sama terjadi selama beberapa waktu

setelah ini, Y terpisah beberapa bagian

\section{Makna Kiru 'potong'}

Makna kiru 'potong' merupakan makna prototipe dari kiru 4 (切る) 'memotong', tatsu (裁つ) 'memotong', dan saidan suru (裁断する) 'memotong'.Walaupun terletak pada ranah semantis yang sama, tetapi tiap verba memiliki perbedaan.Untuk lebih jelasnya dapat dilihat pada contoh verba berikut ini.

Berdasarkan contoh verba kiru 4 (切る) 'memotong' mensyaratkan objek yang kecil berupa gula sachet, verba tatsu (裁つ) 'memotong' mensyaratkan objek yang kecil berupa kain, sedangkan verba saidan suru (裁断する) 'memotong' mensyaratkan objek yang kecil berupa kertas. Isi semantis ketiga verba ini memiliki perbedaanpada kombinasi antar komponen dalam mendeskripsikan makna setiap verba, untuk itu dilakukan parafrase makna seperti ilustrasi di bawah ini.

\section{$\mathrm{Kiru}_{4}$ (切る) 'memotong'}

(a) seseorang $(\mathrm{X})$ melakukan sesuatu pada sesuatu (Y) (gula sachet) dengan sesuatu (Z) selama beberapa waktu karena ini sesuatu terjadi pada sesuatu (Y) seperti yang diinginkannya (b) $\mathrm{X}$ melakukan sesuatu seperti ini ketika mereka melakukan sesuatu pada $\mathrm{Y}$ sebelumnya, mereka memikirkan hal seperti ini: "Y harus terpotong seperti ini "karena ini, aku ingin Y menjadi terpotong dua bagian

(c) ketika melakukan seperti ini, X melakukannya dengan sesuatu yang tajam $(Z)$

$\mathrm{X}$ melakukan sesuatu seperti ini

(d) ketika X melakukan sesuatu dengan Z salah satu tangan $\mathrm{X}$ memegang $\mathrm{Z}$

karena ini tangannya bergerak sesuai dengan keinginan $\mathrm{X}$

$\mathrm{Y}$ ini berpindah sesuai dengan keinginan $\mathrm{X}$

(e) ketika X melakukan seperti ini pada Y dengan Z ujung yang tajam dari $\mathrm{Z}$ mengenai $\mathrm{Y}$

karena ini, ketika tangan $\mathrm{X}$ bergerak sesuai dengan keinginan $\mathrm{X}$ sesuatu terjadi pada tubuh $\mathrm{Y}$

(f) jika hal yang sama terjadi selama beberapa waktu

setelah ini, Y terpotong dua bagian

Tatsu (裁つ) 'memotong'

(a) seseorang (X) melakukan sesuatu pada sesuatu (Y) (kain) dengan sesuatu (Z) selama beberapa waktu

karena ini sesuatu terjadi pada sesuatu (Y) seperti yangdiinginkannya

(b) $\mathrm{X}$ melakukan sesuatu seperti ini ketika mereka melakukan sesuatu pada $\mathrm{Y}$

sebelumnya, mereka memikirkan hal seperti ini:

"Y harus terpotong seperti ini

"karena ini, aku ingin Y menjadi terpotong dua bagian

(c) ketika melakukan seperti ini, X melakukannya dengan sesuatu yang tajam $(Z)$

$\mathrm{X}$ melakukan sesuatu seperti ini

(d) ketika X melakukan sesuatu dengan Z

salah satu tangan $\mathrm{X}$ memegang $\mathrm{Z}$

karena ini tangannya bergerak sesuai dengan keinginan $\mathrm{X}$

$Y$ ini berpindah sesuai dengan keinginan $X$

(e) ketika X melakukan seperti ini pada Y dengan $\mathrm{Z}$ ujung yang tajam dari $\mathrm{Z}$ mengenai $\mathrm{Y}$

karena ini, ketika tangan $\mathrm{X}$ bergerak sesuai dengan keinginan $\mathrm{X}$

sesuatu terjadi pada tubuh Y

(f) jika hal yang sama terjadi selama beberapa waktu

setelah ini, Y terpotong dua bagian 


\section{Saidan suru (裁断する) ‘memotong’}

(a) seseorang (X) melakukan sesuatu pada sesuatu (Y) (kertas) dengan sesuatu (Z) selama beberapa waktu

karena ini sesuatu terjadi pada sesuatu (Y) seperti yangdiinginkannya

(b) $\mathrm{X}$ melakukan sesuatu seperti ini ketika mereka melakukan sesuatu pada Y

sebelumnya, mereka memikirkan hal seperti ini:

"Y harus terpotong seperti ini

"karena ini, aku ingin Y menjadi terpotong dua bagian

(c) ketika melakukan seperti ini, X melakukannya dengan sesuatu yang tajam $(Z)$

$\mathrm{X}$ melakukan sesuatu seperti ini

(d) ketika $X$ melakukan sesuatu dengan $Z$

salah satu tangan $\mathrm{X}$ memegang $\mathrm{Z}$

karena ini tangannya bergerak sesuai dengan keinginan $\mathrm{X}$

$Y$ ini berpindah sesuai dengan keinginan $X$

(e) ketika $\mathrm{X}$ melakukan seperti ini pada $\mathrm{Y}$ dengan $\mathrm{Z}$ ujung yang tajam dari $\mathrm{Z}$ mengenaiY

karena ini, ketika tangan $\mathrm{X}$ bergerak sesuai dengan keinginan $\mathrm{X}$

sesuatu terjadi pada tubuh $\mathrm{Y}$

(f) jika hal yang sama terjadi selama beberapa waktu

setelah ini,Y terpotong dua bagian

Berdasarkan ilustrasi di atas, perbedaan verba kiru $_{4}$ (切る) 'memotong', tatsu (裁つ) 'memotong', dan verba saidan suru (裁断す る) 'memotong' terletak pada komponen (a). Jika perbedaan komponen ini diabaikan, maka dihasilkan struktur sebagai berikut.

(a) seseorang (X) melakukan sesuatu pada sesuatu (Y) $[\ldots]$ dengan sesuatu (Z) selama beberapa waktu

karena ini sesuatu terjadi pada sesuatu (Y) seperti yangdiinginkannya

(b) X melakukan sesuatu seperti ini ketika mereka melakukan sesuatu pada $\mathrm{Y}$

sebelumnya, mereka memikirkan hal seperti ini:

"Y harus terpotong seperti ini

"karena ini, aku ingin Y menjadi terpotong dua bagian

(c) ketika melakukan seperti ini, X melakukannya dengan sesuatu yang tajam $(Z)$

$\mathrm{X}$ melakukan sesuatu seperti ini (d) ketika X melakukan sesuatu dengan Z

salah satu tangan $X$ memegang $Z$

karena ini tangannya bergerak sesuai dengan keinginan $X$

$\mathrm{Y}$ ini berpindah sesuai dengan keinginan $\mathrm{X}$

(e) ketika $X$ melakukan seperti ini pada $Y$ dengan $Z$ ujung yang tajam dari $\mathrm{Z}$ mengenaiY

karena ini, ketika tangan $\mathrm{X}$ bergerak sesuai dengan keinginan $\mathrm{X}$

sesuatu terjadi pada tubuh $\mathrm{Y}$

(f) jika hal yang sama terjadi selama beberapa waktu

setelah ini, Y terpotong dua bagian

\section{Makna Kiru 'menggergaji'}

Makna kiru 'menggergaji' merupakan makna prototipe dari kiru 5 ( 切 る) 'menggergaji' dan setsudan suru (切断す る ) 'memotong'. Walaupun terletak pada ranah semantis yang sama, tetapi tiap verba memiliki perbedaan.Untuk lebih jelasnya dapat dilihat pada contoh verba berikut ini.

Berdasarkan contoh verbakiru5 (切る) 'menggergaji'mensyaratkan objek yang besar berupa papan dan kata sifat perlahan, sedangkan verba setsudan suru (切断する) 'memotong' mensyaratkan objek yang besar berupa pelat besi dan kata sifat cepat. Isi semantis ketiga verba ini memiliki perbedaanpada kombinasi antar komponen dalam mendeskripsikan makna setiap verba, untuk itu dilakukan parafrase makna seperti ilustrasi di bawah ini.

\section{$\boldsymbol{k i r u}_{5}$ (切る) 'menggergaji'}

(a) seseorang (X) melakukan sesuatu pada sesuatu (Y) (papan) dengan sesuatu $(\mathrm{Z})$ untuk beberapa waktu

karena ini sesuatu terjadi pada sesuatu (Y) seperti yang diinginkannya

(b) X melakukan sesuatu seperti ini ketika mereka melakukan sesuatu pada $\mathrm{Y}$ sebelumnya, mereka memikirkan hal seperti ini:

"Y harus terpotong seperti ini

"karena ini, aku ingin Y menjadi terpotong dua bagian 
(c) ketika melakukan seperti ini, X melakukannya dengan sesuatu yang tajam $(Z)$

$\mathrm{X}$ melakukan sesuatu seperti ini

(d) ketika X melakukan sesuatu dengan Z salah satu tangan $\mathrm{X}$ memegang $\mathrm{Z}$

karena ini tangannya bergerak dengan lama sesuai dengan keinginan $\mathrm{X}$

$\mathrm{Y}$ ini berpindah sesuai dengan keinginan $\mathrm{X}$

(e) ketika $X$ melakukan seperti ini pada $Y$ dengan $Z$ ujung yang tajam dari $\mathrm{Z}$ mengenaiY

karena ini, ketika tangan $\mathrm{X}$ bergerak sesuai dengan keinginan $X$ sesuatu terjadi pada $\mathrm{Y}$

(f) jika hal yang sama terjadi selama beberapa waktu

setelah ini, Y terpotong dua bagian

\section{Setsudan suru (切断する) 'memotong'}

(a) seseorang (X) melakukan sesuatu pada sesuatu (Y) (pelat besi) dengan sesuatu (Z) untuk beberapa waktu

karena ini sesuatu terjadi pada sesuatu (Y) seperti yang diinginkannya

(b) $\mathrm{X}$ melakukan sesuatu seperti ini ketika mereka melakukan sesuatu pada Y

sebelumnya, mereka memikirkan hal seperti ini:

"Y harus terpotong seperti ini

"karena ini, aku ingin $\mathrm{Y}$ menjadi terpotong dua bagian

(c) ketika melakukan seperti ini, X melakukannya dengan sesuatu yang tajam $(Z)$

$\mathrm{X}$ melakukan sesuatu seperti ini

(d) ketika X melakukan sesuatu dengan Z

salah satu tangan $\mathrm{X}$ memegang $\mathrm{Z}$

karena ini tangannya bergerak dengan cepat sesuai dengan keinginan $X$

$\mathrm{Y}$ ini berpindah sesuai dengan keinginan $\mathrm{X}$

(e) ketika $\mathrm{X}$ melakukan seperti ini pada $\mathrm{Y}$ dengan $\mathrm{Z}$ ujung yang tajam dari $\mathrm{Z}$ mengenaiY

karena ini, ketika tangan $\mathrm{X}$ bergerak sesuai keinginan $\mathrm{X}$

sesuatu terjadi pada $\mathrm{Y}$

(f) jika hal yang sama terjadi selama beberapa waktu

setelah ini, Y terpotong dua bagian

Berdasarkan ilustrasi di atas, perbedaan verba kiru (切る) 'menggergaji'dan verba setsudan suru ( 切断 する ) 'memotong'terletak pada komponen (a) dan (d). Jika perbedaan komponen ini diabaikan, maka dihasilkan struktur sebagai berikut.

(a) seseorang (X) melakukan sesuatu pada sesuatu (Y) $[\ldots]$ dengan sesuatu (Z) untuk beberapa waktu

karena ini sesuatu terjadi pada sesuatu (Y) seperti yang diinginkannya

(b) $\mathrm{X}$ melakukan sesuatu seperti ini ketika mereka melakukan sesuatu pada Y

sebelumnya, mereka memikirkan hal seperti ini:

"Y harus terpotong seperti ini

"karena ini, aku ingin Y menjadi terpotong dua bagian

(c) ketika melakukan seperti ini, X melakukannya dengan sesuatu yang tajam $(Z)$

$\mathrm{X}$ melakukan sesuatu seperti ini

(d) ketika X melakukan sesuatu dengan Z

salah satu tangan $\mathrm{X}$ memegang $\mathrm{Z}$

karena ini tangannya bergerak [...] sesuai dengan keinginan $\mathrm{X}$

$Y$ ini berpindah sesuai dengan keinginan $X$

(e) ketika $X$ melakukan seperti ini pada $Y$ dengan $Z$ ujung yang tajam dari $\mathrm{Z}$ mengenai $\mathrm{Y}$

karena ini, ketika tangan $\mathrm{X}$ bergerak sesuai dengan keinginan $\mathrm{X}$

sesuatu terjadi pada $\mathrm{Y}$

(f) jika hal yang sama terjadi selama beberapa waktu

setelah ini, Y terpotong dua bagian

\section{SIMPULAN}

Berdasarkan hasil pembahasan diatas, dapat disimpulkan bahwa terdapat 21 verba kiru 'potong' yaitu kiru ( 切る), kiru (切 る), $\mathrm{kiru}_{3}$ (切る), $\mathrm{kiru}_{4}$ (切る), $\mathrm{kiru}_{5}$ (切る), tosatsu suru (屠殺する), sanpatsu suru (散 髪する), $\operatorname{karu}_{1}$ (刚る), $\operatorname{karu}_{2}$ (刚る), $\operatorname{karu}_{3}$ (刈 る), soru (剃る), oru (折る), tsumu (摘む), kizamu (刻む), bassai suru (伐採する), waru (割る), yaburu (破る), saku (裂く), tatsu (裁つ), saidan suru (裁断する), dan setsudan suru (切断する) yang terdiri atas dua kategori, yaitu 1) 'X melakukan sesuatu pada seseorang dibagi atas dua subkategori, yaitu 1.1) ' $\mathrm{X}$ melakukan sesuatu pada seseorang dengan sesuatu terdapat pada verba kiru (切る) 'memenggal'/ 'menebas', 
$\mathrm{kiru}_{2}$ (切る) 'menyayat', tosatsu suru (屠殺 する) 'menyembelih', sanpatsu suru (散髪 する) 'memangkas', karu $_{1}$ ( 刈る) 'memangkas', dan soru ( 剃 る) 'mencukur'dan 1.2) 'X melakukan sesuatu pada seseorang dalam waktu tertentu terdapat pada verba oru ( 折 る ) 'mematahkan', tsumu (摘む) 'memetik', $\mathrm{kiru}_{3}$ (切る) 'mengiris', kizamu (刻む) 'mencincang', $\mathrm{karu}_{2}($ 刈 る) 'membabat', $\mathrm{karu}_{3}$ (刈る) 'menuai', bassai suru (伐採す る) 'menebang', dan waru (割 る) 'membelah'dan 2) 'X melakukan sesuatu pada sesuatu' dibagi atas dua subkategori, yaitu 2.1) 'X melakukan sesuatu pada sesuatu dengan sesuatu' terdapat pada verba yaburu (破る)'merobek', saku (裂く) 'merobek', kiru (切る) 'memotong', tatsu (裁つ) 'memotong', dan saidan suru (裁断 する) 'memotong' dan 2.2) 'X melakukan sesuatu pada sesuatu dalam waktu tertentu' terdapat pada verba kirus (切る) 'menggergaji' dan setsudan suru (切断す る ) 'memotong'. Verba kiru 'potong' dibentuk oleh makna asali yaitu melakukan/terjadi dengan struktur semantis ' $\mathrm{X}$ melakukan sesuatu pada $\mathrm{Y}$ karena ini sesuatu terjadi pada Y.

\section{DAFTAR PUSTAKA}

Bogdan, Robert dan Steven Taylor. (1992). Pengantar Metode Kualitatif. Surabaya: Usaha Nasional.

Goddard, C dan Anna Wierzbicka. (2009). "Contrastive semantics of physical activity verbs: 'Cutting' and 'chopping' in English, Polish, and Japanese". Dikutip dari https://www.researchgate.net/publication /238381757_Contrastive_semantics_of physical_activity_verbs_'Cutting'_and_c
hopping'_in_English_Polish_and_Japane se. Diakses pada tangggal 03 November 2018.

Hardiyanto, Muhammad Ariojati. (2013). Budaya Kuliner Jepang: Bahan Pangan, Pengolahan dan Kandungan Nutrisi. Dikutip dari http://lib.ui.ac.id/file?file=digital/203520 49-MK-

Muhammad\%20Ario\%20Jati\%20Hardia yanto.pdf. Diakses pada tanggal 08 Juli 2018

Kridalaksana, Harimurti.(2007). Pembentukan Kata dalam Bahasa Indonesia. Jakarta: PT. Gramedia Pustaka Utama.

Loe, Efron Erwin Yohanis. (2015). "Verba Memotong Bahasa Rote Dialek Dengka: Kajian Meta Semantik Alami (MSA)". Retorika, 1(2): 403-412.

Lumban Gaol, Gio Vani. (2014). "Verba 'Potong' dalam Bahasa Batak Toba". (Skripsi) Fakutas Ilmu Budaya Universitas Sumatera Utara.

Matsuura, Kenji. (2005). Kamus JepangIndonesia. Jakarta: PT Gramedia Pustaka Utama.

Mulyadi. (2012). "Verba Emosi Bahasa Indonesia dan Bahasa Melayu Asahan: Kajian Semantik Lintas Bahasa". (Disertasi) Program Doktor Linguistik Universitas Udayana.

Putra, I Gusti Ngurah Gumana. (2014). "Verba "Memotong" dalam Bahasa Bali Kajian Metabahasa Semantik Alam". (Tesis) Program Magister Linguistik Universitas Udayana.

Rehana, Ridha. (2016). "Struktur dan Peran Semantis Verba 'AMBIL' dalam Bahasa Aceh". (Tesis) Program Magister Linguistik Universitas Sumatera Utara.

Sudaryanto. (2015). Metode dan Aneka Teknik Analisis Bahasa. Yogyakarta: Sanata Dharma University Press. 
Izumi, Volume 8 No 2, 2019

e-ISSN: 2502-3535 p-ISSN: 2338-249X

Tersedia online di http://ejournal.undip.ac.id/index.php/izumi

Suktiningsih, Wiya. (2017). "Struktur Semantis Verba 'Membawa' Bahasa Sunda: Kajian Metabahasa Semantik Alami”. Dikutip dari https://www.researchgate.net/publication /321239894 STRUKTUR SEMANTIS VERBA MEMBAWA BAHASA SU NDA KAJIAN METABAHASA_SEM ANTIK ALAMI

Van Valin, Robert D. dan Randy J. La Polla. (1997). Syntax: Structure, Meaning and Function. Cambridge University Press.
Wierzbicka, A. (1996). Semantics: Primes and Universals. Oxford: Oxford University Press.

Wiriani,Ni Made. (2017). "Typology Lexical Verb 'To Use' in Japan: Natural Semantics Metalanguage Study". Dikutip dari https://www.researchgate.net/publication /323310139 Typology_Lexical_Verb 'T o_Use'_in_Japan_Natural_Semantics_M etalanguage_Study.

https://zhuanlan.zhihu.com/p/24823641 